\title{
The Use of "KakAyu Dental Flipbook" in Oral Health Knowledge Improvement for Elementary School Students in Depok
}

\author{
Penggunaan "KakAyu Dental Flipbook" dalam Peningkatan Pengetahuan \\ Kesehatan Mulut pada Siswa Sekolah Dasar di Depok
}

\author{
Rikawarastuti*, Eka Anggreni*, Rahaju Budiarti*, Nurlaila Ramadhan Suid**
}

\author{
*Department of Dental Nurse, Jakarta I Health Polytechnic Ministry of Health, Jakarta, Indonesia, **Department \\ of Health Sciences, Atatürk University, Erzurum, Turkey
}

\begin{abstract}
Educating Indonesian children to improve their knowledge about the importance of maintaining oral health is needed. This study was aimed to explain relation between several factors in elementary school students, such as grade, age, sex with number of children in family or economic factor such as whether the mother is housewife or she earns regular income, which is affected by improvement of their oral health education. A quasi experiment pre-test and post-test without control group design involved 141 students as selected through purposive sampling. Samples were distributed to grade IV, V, and VI of private elementary school students in Depok, West Java, Indonesia in April-October 2016. Data collection used pre-test and post-test questionnaires. Data processing used Wilcoxon Signed Rank Test and regression logistic. Results showed the improvement of knowledge level after implementing "KakAyu Dental Flipbook" education. The average result of respondents' knowledge at pre-test was $80.85 \pm 14.17$, and $93.40 \pm 9.84$ at post-test. There is a relation between knowledge improvement and education using "KakAyu Oral Dental/Orthodonthic Flipbook" ( $p$ value $=0.001$ ), but no significant relation between the variables (grade, age, sex, number of family members and mother's working status) and oral health knowledge improvement of elementary school students.
\end{abstract}

Keywords: Dental flipbook, education, elementary school students, knowledge, oral health education

\begin{abstract}
Abstrak
Perlu adanya edukasi untuk meningkatkan pengetahuan anak Indonesia tentang pentingnya memelihara kesehatan gigi dan mulut. Penelitian ini bertujuan untuk menjelaskan hubungan antara faktor siswa sekolah dasar seperti kelas, usia, jenis kelamin dengan jumlah anak dalam keluarga atau faktor ekonomi seorang ibu rumah tangga atau berpenghasilan tetap, yang dipengaruhi oleh peningkatan pengetahuan dari edukasi kesehatan gigi dan mulut. Disain penelitian quasi experiment pre-test dan post-test tanpa desain grup kontrol melibatkan 141 siswa yang dipilih melalui purposive sampling. Sampel tersebar pada siswa kelas IV, V, dan VI sekolah dasar swasta di Depok, Jawa Barat, Indonesia pada April-Oktober 2016. Data penelitian diperoleh dari kuesioner pre-test dan post-test. Wilcoxon Signed Rank Test dan regresi logistik digunakan dalam pengolahan data. Hasil penelitian menunjukkan bahwa tingkat pengetahuan meningkat setelah dilakukan edukasi menggunakan "KakAyu Dental Flipbook". Rata-rata hasil pengetahuan responden saat pre-test 80,85 $\pm 14,17$ dan saat post-test $93,40 \pm 9,84$. Terdapat korelasi antara peningkatan pengetahuan dan edukasi menggunakan "KakAyu Oral Dental/Orthodonthic Flipbook" (nilai $p=$ 0,001), namun tidak terdapat hubungan yang signifikan antara variabel (kelas, usia, jenis kelamin, jumlah anak dalam keluarga, dan status pekerjaan ibu) dengan peningkatan pengetahuan kesehatan mulut siswa sekolah dasar.
\end{abstract}

Kata kunci: Dental flipbook, pendidikan, siswa sekolah dasar, pendidikan, kesehatan mulut

How to Cite: Rikawarastuti, Anggreni E, Budiarti R, Suid NR. The use of "KakAyu Dental Flipbook" in oral health knowledge improvement for elementary school in Depok. Kesmas: National Public Health Journal. 2017; 11 (4): 163-167. (doi:10.21109/kesmas.v11i4.1299)
Correspondence: Rikawarastuti, Department of Dental Nurse, Jakarta I Health Polytechnic Ministry of Health, Wijayakusuma Raya street No. 47 Cilandak South Jakarta, Phone: +6221-75909605, e-mail: rikawarastuti@gmail.com Received: December 6 $6^{\text {th }} 2016$

Revised: February $2^{\text {nd }} 2017$

Accepted: April $3^{\text {rd }} 2017$ 


\section{Introduction}

Children oral health is strongly influenced by parents' habits and knowledge, especially the mother's. Other factors are socio-economic and educational level of parents, gender, values, beliefs, and cultures. Low economic status links with poor oral health. Educated parents tend to take care of their own and their children's teeth better and this good dental habit would affect their childrens's oral health. Children with low socio-economic status whose fathers work and mothers stay at home have more tooth decay, while children from higher social classes were shown to experience fewer caries. ${ }^{1}$ Although parents have the most important role in the oral health of children, teachers also have an important role and should be involved in educating their students because children spend a significant amount of time in school.

School age is an important phase in children's growth, physical development and health because at this age children begin to develop habits that tend to persist into adulthood. One such habit is maintenance of oral hygiene. Oral health behavior in Indonesian children is still poor because there is a lack of knowledge about the importance of maintaining dental hygiene. ${ }^{2}$ Therefore, the maintenance of oral health, especially in school age needs special attention. Primary school age is the ideal time to train the child's motor skills and to improve cognitive skill. Since children have a short attention span (reference), they need a fun and motivating way to learn. In addition, effective learning involves not only providing information, but also hands-on experience. ${ }^{3}$ In this regard, relevant learning media is vital to the learning process. Media that can show the learning materials of oral health in an interactive form such as text, images, audio, video, and animation are more engaging, interesting and fun. Selecting appropriate and effective learning media can make a positive contribution to learning and help improve the efficiency and effectiveness of learning activities, improve motivation, interests, and activities of participants, increase the interest in learning and understanding the concepts, increase participant's motivation to study hard, and improve participants' critical thinking skills. ${ }^{4-7}$

A study found that education and counseling using an integrated and interactive media education approach can increase knowledge and change behavior. ${ }^{8}$ Multimedia is able to provide advantages not shared by other types of learning media because multimedia stimulates multiple senses. Especially, sight and sound enables the learning of phenomena that are not possible when presented with more traditional media. Moreover, multimedia can generate interest and increase students' motivation.

"KakAyu Dental Flipbook" learning media was developed prior the study. The "KakAyu Dental Flipbook" has been validated by subject matter experts, media experts, teachers, and students of the school and is considered ready for use. The flipbook is expected to improve elementary students' knowledge about oral health. In this study, we aim to evaluate the elementary school students knowledge about oral health before and after education with KakAyu Oral Dental/Orthodontic Flipbook.

\section{Method}

Prior to the study, "KakAyu Dental Flipbook" using a model called ADDIE (Analyze, Design, Develop, Implement, Evaluate) had began to be developed. "KakAyu Dental Flipbook" was taken from the initials name of Flipbook maker. The flipbook was enriched with pictures, video and animated files with additional background color and images, control buttons, navigation bars, and pages to display "KakAyu Dental Flipbook" content. ${ }^{9}$ Figure 1 presents example pages from "KakAyu Dental Flipbook".

The study was conducted from April to October, 2016 at private school students in Depok, West Java, Indonesia. This study was quasi experimental pre-test and post-test without a control group. Using purposive sampling, total of 141 students were selected and asked to sign a written informed consent before participating in the study. The sampling criteria were students who were in class IV, V, and VI at the National Plus Tunas Iblam Elementary School in Depok, West Java, Indonesia; had not received oral health lessons in the last one year; had a dental clinic at their school, were willing to be a respondent; were willing to take the pre-test; were willing to attend the "KakAyu Dental Flipbook" lessons; and were willing to take the post-test. ${ }^{1-7}$

The respondents completed two questionnaires, the pre-test and the post-test. Interval between pre-test and post-test was 35 days because of many curricular activities in school in the last week. The ideal timing between pre-test and post-test is 15-30 days. If too short, the respondents may still remember the questions in the pre-test and too long, may change the respondent variable measurement. ${ }^{10}$ The dental lesson was given using the flipbook for 30 minutes to 20-25 students at the computer school laboratory. The post-test took 10-20 minutes after the students finished learning from the "KakAyu Dental Flipbook". The post-test contained 10 questions which evaluated the student's knowledge of oral health, including their knowledge about the characteristics of healthy teeth, what food to avoid to prevent tooth decay, what to eat to maintain dental health, how to clean the plaque, the selection brush their teeth, while brushing teeth, how to brush the benefits of fluoride to the teeth, cavities symptoms, and dental examination and treatment. Baseline data were gathered with a questionnaire in which students circled answers. At the time of counseling, students were actively and independently able to 


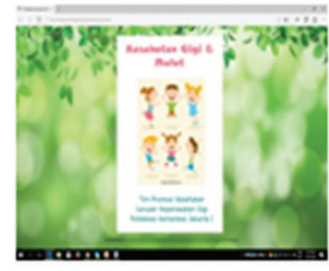

Cover

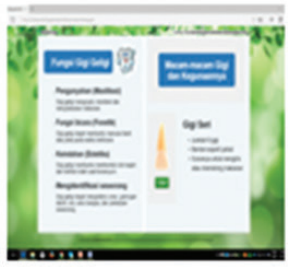

Sample page content, text and details

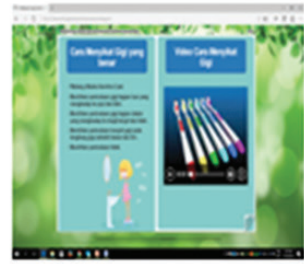

Combined with video and sound

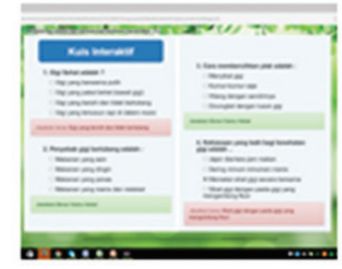

Interactive quiz

Figure 1. "KakAyu Dental Flipbook"

open and read the flipbook, and they received guidance. The questionnaire contained 15 items with the first five regarding respondent characteristics include grade, age of child, sex, number of family members, and mother's working status. There were 10 items designed to measure children's knowledge about oral health. Validity and reliability of the questionnaire was tested on 50 children from a group of targeted respondents and test results showed that there were 10 items of valid questions $($ Cronbach's alpha $=0.729)$ and reliable $(\mathrm{R}$ table $=$ 0.273). Data analysis used Wilcoxon Signed Rank Test and logistic regression.

Oral health knowledge level of respondents was grouped into two categories, namely less good and good. Referring to the rating scale the level of knowledge was less good if correct answers were less than $80 \%$, and good if correct answers were greater than or equal to $80 \% .11$

\section{Results}

Table 1 shows the level of knowledge pre-test and post-test. Normality test on the knowledge level for pretest and post-test were analyzed by the Shapiro-Wilk ( $p$ value $<0.005$ ), while the improvement of knowledge was $\mathrm{p}$ value $<0.005$ (skewness). Wilcoxon Signed Rank test found the following results in Table 2.

Wilcoxon Signed Rank Test showed the $\mathrm{Z}$ value of 7.943 with $p$ value $<0.005$ which means that there were significant differences in the knowledge level between group pre-test and post-test. The influence of the children's and parents' characteristics on knowledge was determined by multivariate analysis. Two categories were defined by score of knowledge; increase if knowledge score has increased and decrease if knowledge has decreased or unchanged. The average difference in knowledge was $12.5 \%$. Bivariate analysis results can be seen in the following Table 3.

Table 3 shows that grade and number of family members had $p$ value $<0.250$, so were entered in the multivariate analysis. Table 4 presents none of the characteristics of children and parents were associated with knowledge level.
Table 1. Oral Health Knowledge Level of Respondents

\begin{tabular}{llrr}
\hline & & \multicolumn{2}{c}{ Total } \\
\cline { 3 - 4 } Variable & Category & $\mathbf{n}$ & $\%$ \\
\hline Knowledge level & & & \\
Pre-test & Less good & 41 & 29.1 \\
& Good & 100 & 70.9 \\
Post-test & Less good & 9 & 6.4 \\
& Good & 132 & 93.6 \\
\hline
\end{tabular}

Notes:

$\mathrm{n}=$ Number of Sample; $\%=$ Percentage

Table 2. Average Difference Analysis of Oral Health Knowledge Level Before and After Educating with "KakAyu Dental Flipbook"

\begin{tabular}{lcccc}
\hline Variable & Mean & $\begin{array}{c}\text { Standard } \\
\text { Deviation }\end{array}$ & $\mathbf{Z}$ & $\begin{array}{c}\text { p Value } \\
\mathbf{( 9 5 \% ~ C I ) ~}\end{array}$ \\
\hline Knowledge & & & & \\
Pre-test & 80.85 & 14.17 & -7.943 & 0.000 \\
Post-test & 93.40 & 9.84 & & \\
\hline
\end{tabular}

Note:

$\mathrm{CI}=$ Confidence Interval

\section{Discussion}

This study involved 141 students. Students were divided into grade IV, V and VI. Students were also divided into girls and boys groups. The ages were between 8-12 years, with a median age of 10 years. More than half of the students had less than or equal to two children with unemployed mothers. Age of students in private schools tend to be younger than in public schools. In private schools, the prospective students of first grade can be accepted at the age of less than 7 years old while the government policy requires that state primary school entry age is 7 years. The average age of students in grade IV and $\mathrm{V}$ was $12-13$ years. In regards to gender, private schools provided equal opportunities for boys and girls, so distribution of students by gender was equal.

The results of this study showed that the average knowledge score achieved by students in the pre-test was 80.85 and this increased to 93.40 in the post-test. The proportion of students with scores in the 'good' category increased from $70.9 \%$ in the pre-test to $93.6 \%$ in the post-test. These results illustrates an increasing of ave- 
Table 3. Relation between Characteristics and Knowledge Level of Respondents

\begin{tabular}{|c|c|c|c|c|c|c|c|}
\hline \multirow{3}{*}{ Variable } & \multirow{3}{*}{ Category } & \multicolumn{4}{|c|}{ Score } & \multirow{3}{*}{ OR $(95 \% \mathrm{CI})$} & \multirow{3}{*}{ p Value } \\
\hline & & \multicolumn{2}{|c|}{ Increase } & \multicolumn{2}{|c|}{ Decrease } & & \\
\hline & & $\mathbf{n}$ & $\%$ & $\mathbf{n}$ & $\%$ & & \\
\hline \multirow[t]{3}{*}{ Grade } & IV & 13 & 27.1 & 35 & 72.9 & & \\
\hline & $\mathrm{V}(1)$ & 12 & 25.5 & 35 & 74.5 & $1.73(0.73-4.13)$ & $0.200 *$ \\
\hline & VI (2) & 18 & 39.1 & 28 & 60.9 & $1.87(0.76-4.54)$ & $0.160 *$ \\
\hline \multirow[t]{2}{*}{ Age of child } & $\leq 10$ years & 28 & 28.3 & 71 & 71.7 & $0.70(0.33-1.53)$ & 0.700 \\
\hline & $>10$ years & 15 & 35.7 & 27 & 64.3 & & \\
\hline \multirow[t]{2}{*}{ Sex of child } & Boys & 19 & 26.4 & 53 & 73.6 & $0.77(0.33-1.38)$ & 0.360 \\
\hline & Girls & 24 & 34.8 & 45 & 65.2 & & \\
\hline \multirow[t]{2}{*}{ Number of family members } & $\leq 2$ & 21 & 25.0 & 63 & 75.0 & $0.53(0.26-1.09$ & $0.090 *$ \\
\hline & $>2$ & 22 & 38.6 & 35 & 61.4 & & \\
\hline \multirow[t]{2}{*}{ Mother's working status } & Unemployed & 22 & 31.0 & 49 & 69.0 & $1.05(0.51-2.15)$ & 1.000 \\
\hline & Employed & 21 & 30.0 & 49 & 70.0 & & \\
\hline
\end{tabular}

Notes:

$\mathrm{OR}=$ Odds Ratio; $\mathrm{CI}=$ Confidence Interval; *Multivariate Variable Candidate

Table 4. Multivariate Modelling related to Knowledge Level

\begin{tabular}{|c|c|c|c|c|c|c|c|}
\hline \multirow{2}{*}{ Variable } & \multirow{2}{*}{$\beta$} & \multirow{2}{*}{ SE } & \multirow{2}{*}{ Wald } & \multirow{2}{*}{ p Value } & \multirow{2}{*}{ OR } & \multicolumn{2}{|c|}{ 95\% CI } \\
\hline & & & & & & Lower & Upper \\
\hline Number of family members & 0.63 & 0.3 & 2.93 & 0.08 & 1.8 & 0.91 & 3.90 \\
\hline
\end{tabular}

rage score before and after educated by using "KakAyu Dental Flipbook". Improvement can be seen from the average pre-test score $80.85 \pm 14.17$ which increased to $93.40 \pm 9.84$ for the post-test. There was a correlation between the increase of knowledge by the use "KakAyu Dental Flipbook" while doing education and outreach for the respondents ( $\mathrm{p}$ value $<0.005$ ).

Using multimedia can be more effective and efficient in conveying information. Multimedia uses a combination of several different media in the form of text, audio, graphics, animation, and multimedia video. Technology media can be used for oral health education. The use of multimedia can result in someone remembering up to $90 \%$ of what they read, hear, see, say and make. ${ }^{12}$

Results of this study are in line with study conducted in Aborigines on educational interventions in improving knowledge of dental work, which suggests education interventions including the promotion and extension of knowledge of dental care and brushing in order to increase children's knowledge of Aborigines overall, but needed a follow up to determine if there are any longterm improvement in the health of the mouth. ${ }^{13}$

The use of instructional media can be as diverse as power point, illustrated stories, flipcharts, demonstrations, and games. There have been many studies that tried to compare the effectiveness of the use of different media. Study conducted at the Jember Patrang 2 State Elementary School indicated that the media snake ladder game effectively and significantly improved the knowledge, attitudes and practices in maintaining oral health more than a media picture story. ${ }^{14}$ Similarly, the study of fourth grade students of Sukorejo 02 and 03 State Elementary Schools in Gunungpati District indicated a difference in the improvement of knowledge of oral health between using media power point and flip chart. ${ }^{15}$

However, these studies did not use computer-based learning media, while this study developed media learning aids such as flipbook which can be operated on a computer, laptop, or tablet. As an information technology tool, the use of computers, laptops, or tab will attract student's interest and make learning active and fun. ${ }^{16}$ Some of the advantages of computer media for learning programs include, the ability to accommodate students whith slower progress through the lesson, to stimulate students in doing exercises or simulations because of the availability of animations that can add realism, to match the pace of teaching with the pace of learning, and to record student activity which would provide a better opportunity for individual learning and development as each student can always be monitored.

This study did not find a relation between child characteristics (grade, age of child, sex of child) or parent characteristics (the number of family member and the mothers' working status) with the level of oral health knowledge. These results do not differ from another study which states that there was no relation between 
sex and variables including knowledge, attitudes and behaviors relating to oral hygiene care. 17

This study also found no relation between age and level of knowledge ( $p$ value $=0.124)$. These results are in line with a study conducted on 6-12-year-old students in Istanbul which found that there was no relation between age and knowledge of dental health. ${ }^{18}$ Primary school age is the right time for health promotion because children's cognitive skills began to develop on something concrete, rational and objective as their way of thinking. ${ }^{19}$ Naturally, children in primary school age has shown sensibility to learn as their sense of wonder.

Mothers who do not work often have the opportunity to pay attention to their children's oral health. ${ }^{20}$ Study done on 6 - 12-year-old students in Istanbul stated that there was a significant relation between the number of children in the family ( $\mathrm{p}$ value $=0.009$ ) and a mother who did not work ( $p$ value $<0.005$ ) with oral health knowledge. ${ }^{18}$ However, in this study the number of child and maternal employment status was not significantly related to students' knowledge. Other factors were related to the students' knowledge, such as the knowledge level of the mother and family economic status.

\section{Conclusion}

The result of this study provide preliminary evidence for the effecacy of education with 'KakAyu Dental Flipbook'. This significance was not retained when split by grade, age, sex, number of family members, and mother's working status.

\section{Recommendation}

There is a need for further study to investigate whether short-term retention of oral health knowledge translates into long-term retention and, most importantly, altered oral hygiene practices.

\section{Acknowledgment}

We would like to express our gratitude to Riset Pembinaan Tenaga Kesehatan Jakarta I Health Polytechnic Ministry of Health for funding this study.

\section{References}

1. De Castilho ARF, Mialhe FL, De Souza Barbosa T, Puppin-Rontani RM. Influence of family environment on children's oral health: a systematic review. Journal de Pediatria (Rio J). 2013; 89(2): 116-23.

2. Fankari F. Pengaruh penyuluhan dengan metode stimulasi dan demonstrasi terhadap perubahan perilaku menjaga kesehatan gigi dan mulut anak sekolah dasar [karya tulis ilmiah DIV]. Yogyakarta: Universitas Gajah Mada; 2004.

3. Notoatmodjo S. Promosi kesehatan dan ilmu kesehatan. Jakarta: Rieneka Cipta; 2010.
4. Sugiyanto. Modul virtual: multimedia flip book dasar teknik digital. INVOTEC. 2013; 9(2): 101-16.

5. Nazeri. Penggunaan e-flipbook dalam topik elektrik dan elektronik: inovasi dalam pengajaran reka bentuk dan teknologi PISMP RBT. Prosiding Seminar Penyelid IPG Zon Timur. 2013; 1(1).

6. Tirta NIN, Santyasa IW, Warpala IWS. Pengembangan multimedia interaktif berbasis proyek dengan model ADDIE pada materi pemrograman web siswa kelas X semester genap di SMK Negeri 3 Singaraja. E-jurnal Program Pascasarjana Universitas Ganesha Program Studi Teknologi Pembelajaran. 2014; 4: 1-10.

7. Mairiska T. Pengembangan perangkat pembelajaran berbasis TPACK pada materi sifat koligatif larutan untuk meningkatkan ketrampilan berfikir kritis siswa. Edu-Sains: Jurnal Pendidikan Matematika dan Ilmu Pengetahuan Alam [Internet]. 2014 [cited 2015 Aug 15]. Available from: unja.ac.id/index.php/edusains/.../1153

8. Hudayani F, Ayu R, Sartika D. Knowledge and behavior change of people living with HIV through nutrition education and counseling. Kesmas: National Public Health Journal. 2016; 10(3): 107-12.

9. Rikawarastuti R, Anggreni E, Rahaju B. Development of flipbook dental and oral health. In: International Conference on Health Polytechnic Surabaya. Surabaya: Health Polytechnic Ministry of Health Surabaya Indonesia. 2016; p. 404-7.

10. Notoatmodjo S. Promosi kesehatan dan ilmu perilaku. Jakarta: Rieneka Cipta; 2007.

11. Sugiyono. Metode penelitian kuantitatif kualitatif dan R \& D. Bandung: Alfabeta CV; 2010.

12. Hadnyanawati H. Pemanfaatan multimedia sebagai media penyuluhan kesehatan gigi. Indonesia Journal Dentistry. 2007;14(3):177-80.

13. Chen CC, Huang HK, Huang MJ, Wu CH. Educational intervention can improve dental care knowledge in Aboriginal Tribal children. Tzu Chi Medical Journal [Serial on Internet]. 2011; 23(3): 86-9. Available from: http://dx.doi.org/10.1016/j.tcmj.2011.08.002

14. Hamdalah A. Efektivitas media bergambar dan ular tangga dalam pendidikan kesehatan gigi dan mulut siswa SDN 2 Patrang Kebupaten Jember. Jurnal Promosi Kesehatan. 2013;1 (2): 118-23.

15. Nurhidayat O, Bambang W. Perbandingan media power point dengan flipchart dalam meningkatkan pengetahuan kesehatan gigi dan mulut. Unnes Journal of Public Health. 2012; 1 (1): 31-5.

16. Arsyad A. Media pembelajaran. Jakarta: PT. Raja Grafindo Perkasa; 2006.

17. Nurchasanah S. Hubungan jenis kelamin, tempat tinggal, pengetahuan, sikap dan dukungan orangtua dengan status kesehatan gigi siswa sekolah dasar di Kabupaten Sleman [thesis]. Yogyakarta: Gadjah Mada; 2006.

18. Çolagoklu N, Has E. The evaluation of the effects of socio-demographic factors on oral and dental health: a study on the ages 6-12. Procedia-Soc Behavior Science. 2015; 195: 1278-87.

19. Santrock JW. Psikologi perkembangan. 11th ed. Jakarta: Erlangga; 2007.

20. Yulianti RP. Muhlisi A. Hubungan antara pengetahuan orangtua tentang kesehatan gigi dan mulut dengan kejadian karies gigi pada anak di SDN V Jaten Karanganyar. Jurnal Universitas Muhammadiyah Surakarta. 2011; (1999): 25-34. 